\title{
Diversity of a semi-arid, intact Mediterranean ecosystem in southwest Australia
}

\author{
Simon Judd, James E. M. Watson and Alexander W. T. Watson
}

Judd, S., Watson, J. E. M. and Watson, A. W. T. 2008. Diversity of a semi-arid, intact Mediterranean ecosystem in southwest Australia. - Web Ecol. 8: 84-93.

\begin{abstract}
The drier parts of the Mediterranean biome of southwest Australia contain the largest remaining Mediterranean woodlands and shrublands on Earth. Despite this, there has been no formal, comprehensive assessment of their biodiversity. The region abuts the southwest Australian floristic region which has received much scientific attention. The aim of this paper is to provide the first general overview of the biodiversity of part of this intact, yet relatively unknown, Mediterranean ecosystem. We do this by synthesizing data from State Government agencies and published research. We found that, like other parts of southwest Australia, the region has globally significant levels of plant species diversity. More than 2400 plant species, including 291 species considered threatened, have been recorded, representing one-sixth of all Australia's vascular plant species. Eleven of Australia's 23 major vegetation groups are represented even though the region covers less than $1 \%$ of continental Australia. We documented 170 vertebrate species, including 31 threatened species, with a particularly high richness of reptile species $(\mathrm{n}=46)$. We highlight how little is known about this region. For example, 116 vertebrate species not recorded in the region probably occur there based on their habitat requirements and known distributions. An examination of plant and vertebrate diversity in the region, using a half degree latitude and longitude grid cells, showed a highly heterogeneous pattern of species richness and vulnerability, with a general decline in species richness from southwest to northeast. Conservation strategies that rely on capturing the highest levels of biodiversity in a series of protected areas are unlikely to guarantee protection for all species given these high levels of heterogeneity. Instead, a region-wide conservation plan should involve targeted ecological research, consideration of ecological processes and stakeholder consultation.
\end{abstract}

S. Judd (simon_judd@iprimus.com.au), School of Natural Sciences, Edith Cowan Univ., 100 Joondalup Drive, Joondalup, WA 6027, Australia. - J. E. M. Watson, The Ecology Centre, School of Integrative Biology, Univ. of Queensland. QLD 4072, Australia. - A. W. T. Watson, The Wilderness Society, 2 Delhi St, West Perth, WA 6005, Australia.

Six of Australia's ten Mediterranean ecoregions are located in southwest Australia (Wilson et al. 2007). These we refer to collectively as the southwest Australian Mediterranean biome (SWAMB). It is an island-like (Hopper 1979), relatively wet continental refuge bordered on two sides by ocean, and isolated by arid lands to the north, northeast, and east. Topographically it is unique among the world's five regions of Mediterranean climate as it is a flat, stable, highly-weathered plateau with granite occasionally emergent as domed inselbergs (Anand and Paine 2002, Hopper

Accepted 10 June 2008

Copyright (C) EEF

ISSN 1399-1183 
and Gioia 2004) (photo 1). The last glacial event occurred in the Permian so the region is very old, with highly nutrient-deficient soils (Hopper et al. 1996).

Much of the SWAMB is considered a global biodiversity hotspot (Myers et al. 2000) for two reasons; it has high levels of plant species richness and endemism (Hopper and Gioia 2004), and a large degree of historical habitat modification (Hopper and Muir 1984). Southwest Australian landscapes are among the most heavily utilized on the planet with almost 20 million ha of native vegetation replaced or modified for broad-scale agriculture in the second half of the 20th century (Cody 1986, Greuter 1994, Yates et al. 1999, Hopper 2003, 2004). Our knowledge of the biodiversity of the SWAMB is dominated by research undertaken in highly fragmented landscapes located in the western part, most of which has had its original vegetation removed, or extensively modified due to higher annual rainfall and, hence, greater potential agricultural or timber productivity (Watson et al. 2008; Fig. 2). There is a plethora of research highlighting the detrimental impact of habitat loss, degradation and fragmentation on a range of threatened, range-restricted taxon and com- munities (Hobbs and Atkins 1991, Saunders et al. 1992, Saunders and Ingram 1995, Arnold and Weeldenburg 1998, Hobbs and O'Connor 1999, Abensperg-Traun et al. 2000).

Very little is known about the biodiversity of the less disturbed, eastern portion of the SWAMB. Hopper and Gioia's (2004) research on the evolution and distribution of plant species in southwest Australia ends at the southwest Australian floristic region (SWAFR) boundary, and not the edge of the Mediterranean climatic zone itself (Fig. 1). The aim of this paper is to provide a framework that complements Hopper and Gioia’s (2004) paper and synthesizes the current knowledge of biodiversity in the lesser known region beyond the SWAFR.

The fact that this eastern part of the SWAMB has not been subject to large broad-scale clearing relative to other Mediterranean ecosystems (Fig. 2), provides an insight into a system that is primarily influenced by 'natural' disturbance regimes which has implications for the management of both natural areas and adjacent modified areas. We conclude the paper with a short discussion of the requirements for conservation planning in the region.

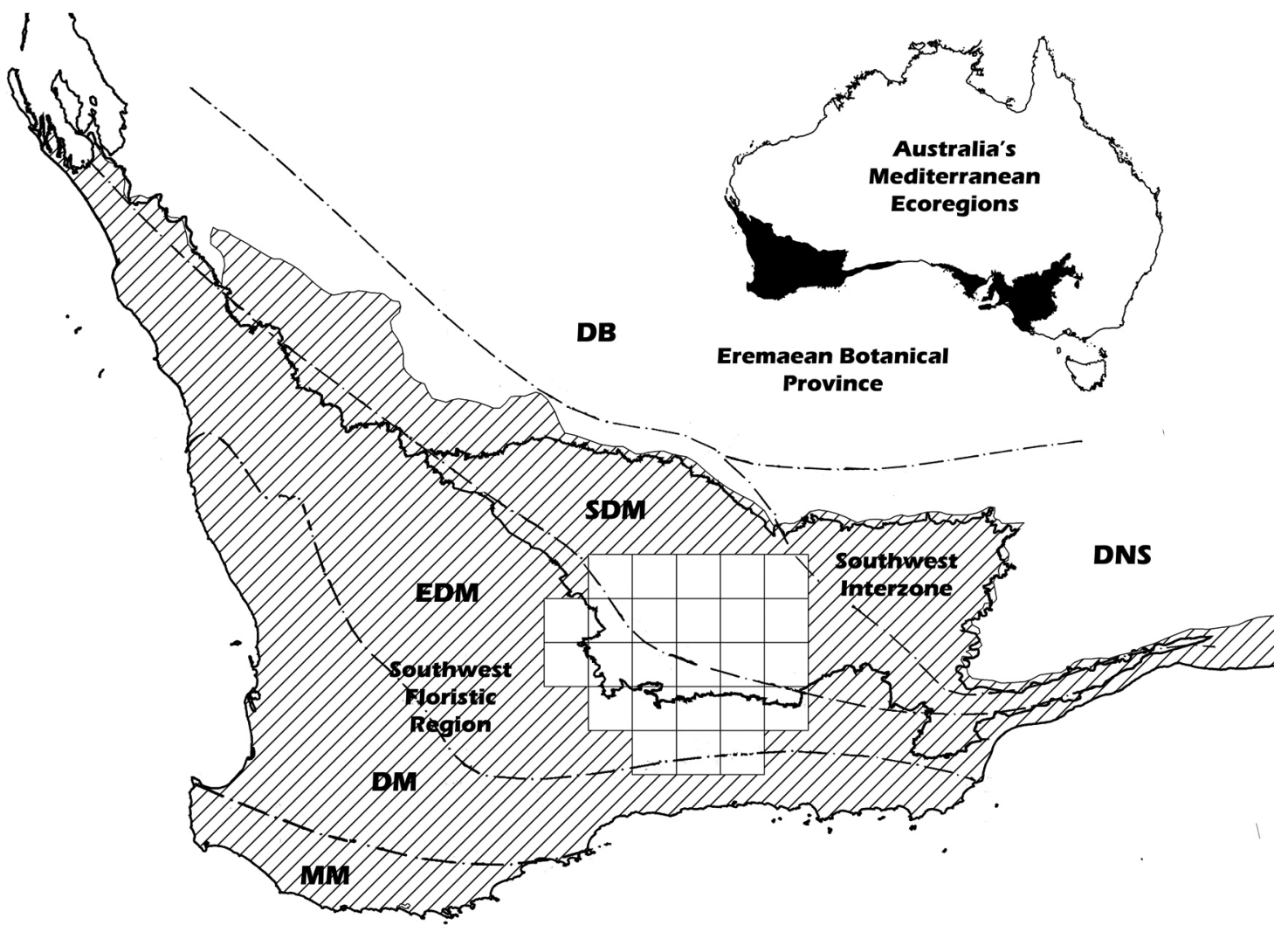

Fig. 1. The location of our study area (gridded) shown in relation to Mediterranean southwest Australia sensu Wilson et al. (2007) (hatched), the southwest Australian floristic region (Beard 1980, Hopper and Gioia 2004) and the southwest interzone (Beard 1980) (bold lines). The climate zones of Beard (1984); moderate Mediterranean (MM), dry Mediterranean (DM), extra-dry Mediterranean (EDM), semi-desert Mediterranean (SDM) desert bixeric (DB) and desert non-seasonal (DNS) are also shown (dotted lines). 


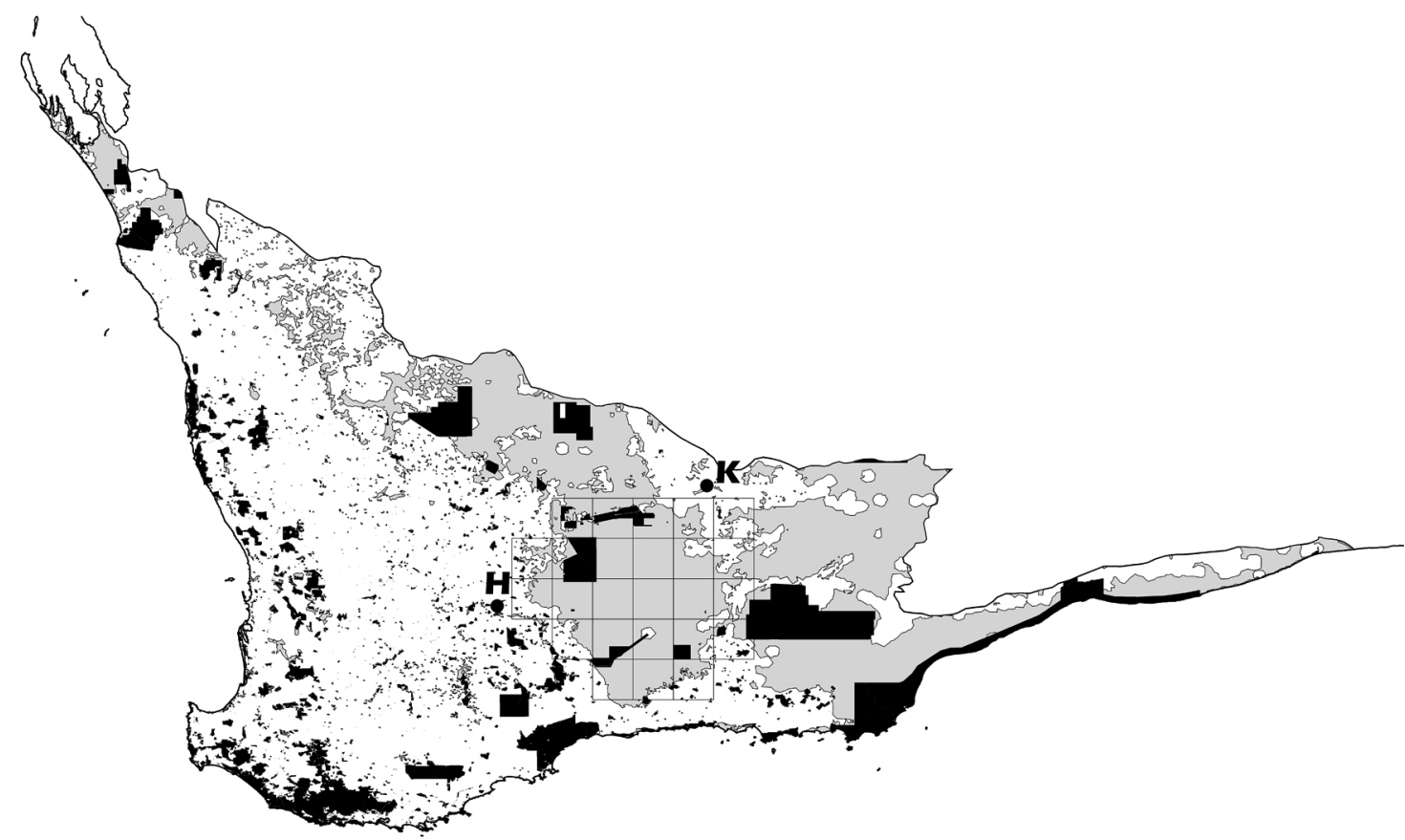

Fig. 2. Mediterranean southwestern Australia sensu Wilson et al. (2007) and the location of our study area (grid) shown in relation to categories 0 and I (e.g. intact vegetation) in the VAST framework developed by Thackway and Leslie (2006) (grey). National parks and nature reserves (black), and Kalgoorlie $(\mathrm{K})$ and Hyden $(\mathrm{H})$ are shown.

\section{Methods}

\section{Study area}

Given the debate about the boundaries of Mediterranean ecosystems and biomes (Cowling et al. 1996), we followed Wilson et al.'s (2007) definition of the southwest Mediterranean biome and Beard's (1984) climatic gradients of moderate, dry, extra-dry and semi-desert Mediterranean bioclimatic zones (Fig. 1).

We limited our study area to the relatively unknown, eastern portion of the SWAMB (Fig. 1, 2). The study area straddles the extra dry Mediterranean and semi-desert Mediterranean bioclimatic zones. We stratified our research by conducting our assessment in a region with predominately intact native vegetation. We defined vegetation intactness using the Vegetation Assets, States, and Transitions (VAST) framework of Thackway and Lesslie (2006). The VAST framework classifies the Australian vegetation by degree of human modification from pre-European settlement conditions as a series of states using the criteria of floristic composition, vegetation structure and regenerative capacity. Seven classes are mapped on a $1 \times 1 \mathrm{~km}$ grid across Australia, and these classes range from 0 (unmodified natural bare ground) and I (unmodified native vegetation), to VI (removed, transformed to non-vegetation land use) (Thackway and Lesslie 2006). We selected VAST classes 0 and I to represent intact vegetation because they identify areas dominated by native vegetation and where there has been no extensive clearing or fragmentation from land use activities (Fig. 2).

The study area covers approximately 5.6 million hectares (Fig. 1) within which there are 4.7 million hectares of intact vegetation (Fig. 2). The southern and western boundaries of the study area represent the edge of the cleared agricultural land. The area experiences an eastward trend of both declining rainfall and decreasing dominance of winter rainfall (Beard 1984). For example, the average annual rainfall for Hyden $\left(118^{\circ} 55^{\prime} \mathrm{E}\right.$, Fig. 2) is $343 \mathrm{~mm}$

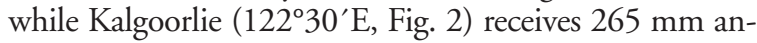
nual rainfall (Bureau of Meteorology 2008).

\section{Data collation}

Initially, we aimed to collate records of all taxa collected or observed in the study area. After a review of the literature we decided to focus on flowering plants and vertebrates because very little data collection had been undertaken on the other taxa (e.g. invertebrates, fungi, lichens) and the information available was disparate. This synthesis is primarily based on publically available data sets from Western Australian Government agencies. For flowering plants we used the Western Australias Department of Conservation and Environment FloraBase (data base, <http://florabase. 


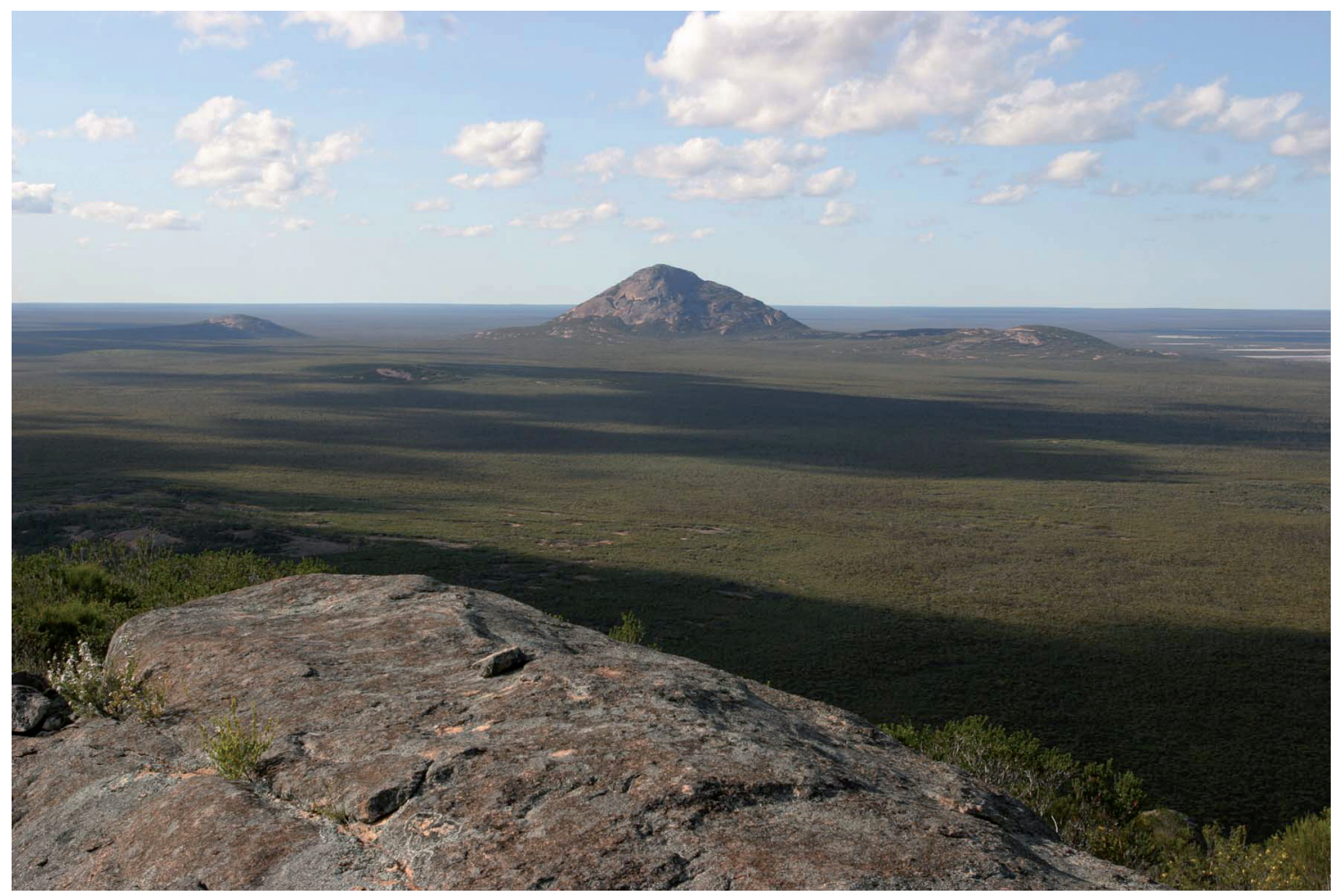

Photo 1. A landscape including the highest point in the study area (Peak Charles). Photo by Charles Roche.

calm.wa.gov.au/prod/index.htm>). The Western Australia Herbarium supplied species lists and the total number of records for each of 25 grid cells (Data analysis). These lists were tabulated to produce a matrix of plant taxa and grid cells.

Vertebrate data was extracted from the Western Australian Museum's FaunaBase (<http://www.museum.wa.gov. $\mathrm{au}$ /faunabase >) which is a list of the specimens held by the Western Australia Museum. This does not discriminate between methodologies used to gather the data nor does it allow for separation of the findings of discrete research projects. In order to get a more detailed picture of the vertebrate species in the region we tabulated data from three extensive, peer-reviewed biological surveys (Newbey et al. 1984, Keighery et al. 1995, How et al. 1998) and Australian Bird Atlas (<http://www.birdsaustralia.com. au/our-projects/atlas-birdata.html $>$ ) data purchased from Birds Australia. The vertebrate data was prepared in the same way as the plant data.

\section{Data analysis}

We examined two common expressions of biological diversity. Firstly, we tabulated and mapped the geographical richness of vascular plants and vertebrate species using presence data in a series of half degree grid cells across the study area based on latitude and longitude. For floristic studies in the SWAMB Hopper and Gioia (2004) used quarter-degree cells and Hopper (1992) used one degree grid cells. We present the data in half degree cells because at spatial scales smaller than this we found the number of samples per cell were too small. At a larger scale than half degree the number of cells became too small for any determine meaningful geographic trends.

It was not possible to assess the sampling bias for each of the data sets. This is because the datasets indicate the presence or absence within a grid cell and represent a range of methodologies. These include systematic searches within quadrates through to individual 'chance' observations. As a consequence, we did not conduct diversity or similarity analyses but treat the data more as an inventory of the region at the broad scale.

Secondly, we examined ecosystem diversity within the study area by comparing two different vegetation datasets for the region. We analysed the vegetation dataset of Beard (160 map sheets at 1:250 000 done via aerial photo interpretation combined with field reconnaissance of dominant species and structure) which is available as the Pre-European Vegetation Theme from the Western Department of Agriculture and The National Vegetation Inventory, which is the first Australia-wide assessment of the type and extent of Australia's native vegetation (Commonwealth of Australia 2001). These data were trimmed to the SWAMB 


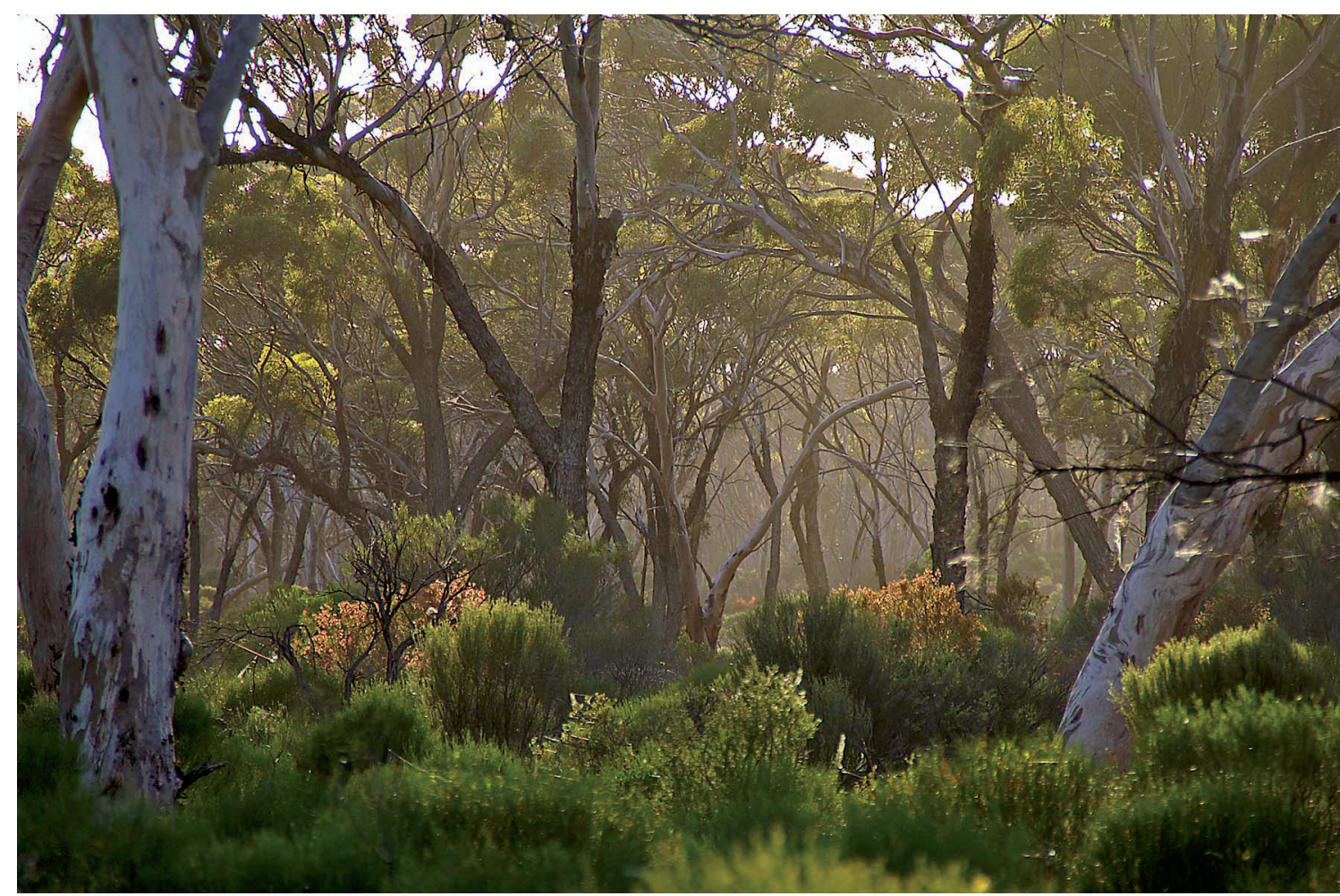

Photo 2. Eucalypt woodlands are the most extensive of Australia's major vegetation groups found within the study area. Photo by Barbara Madden.

and to the study area to conduct comparative quantitative analysis using ArcMap ${ }^{\mathrm{TM}}$ 9.1.

\section{Results}

\section{Floristic diversity}

Records from the Western Australian Herbarium show that at least 2800 flowering plant taxa (subspecies, hybrids, varieties and possible new species) have been recorded in the study area representing 2473 species from 103 families. Species richness is relatively evenly distributed across the landscape (Fig. 3a), although there is a trend of increasing richness towards the southwest of the study area. This area is part of the SWAFR which is known to be floristically richer and this does not appear a result of more intensive sampling (Fig. 3b). The number of plant data records in each cell varied from 155 to 2135 , with an average amount of records for each cell being 1026.7 (SE \pm 106.2). However, the cells with lower numbers of species and records are those furthest from major towns indicating that these may be richer than shown due to less sampling effort. An important feature of the cell analysis is that many plant species have very localized geographic ranges.
No plant taxa were found in all the grid cells. In addition, more than half the taxa were recorded in three cells or less (861 species in one cell, 539 in two cells and 357 taxa in three cells). This suggests that vegetation communities are highly heterogeneous across the study area.

The study region contains plant species considered threatened by past and present human activities. Twentythree species are listed as 'declared rare flora' because they are rare, in danger of extinction, or in need of special protection (Dept of Environment and Conservation 2008). A further 272 species have been listed as 'priority' species, because they are known from just one or only a few populations which are under threat, either due to small population size, or threats to their location. These 295 species are distributed throughout the study area (Fig. 3c). Again, the southwest corner of the study area appears to contain more priority and threatened species and there is a general decline in the number of these species from southwest to northeast.

\section{Vertebrate diversity}

The floristic and structural diversity of plant communities across the study area provides habitat for many species of vertebrates. We documented 36 mammal species, 103 


\begin{tabular}{|c|c|c|c|c|c|}
\hline & 515 & 427 & 482 & 331 & 326 \\
\hline 295 & 530 & 184 & 116 & 109 & 299 \\
\hline \multirow[t]{2}{*}{635} & 631 & 331 & 306 & 150 & 603 \\
\hline & 670 & 931 & 451 & 552 & 468 \\
\hline $\boldsymbol{d}$ & & 744 & 495 & 456 & \\
\hline
\end{tabular}

\begin{tabular}{|l|l|l|l|l|l|}
\hline \multicolumn{1}{c|}{} & 1268 & 1201 & 1305 & 858 & 814 \\
\hline 551 & 965 & 260 & 176 & 155 & 692 \\
\hline 1475 & 1706 & 582 & 751 & 288 & 2135 \\
\hline & 1667 & 960 & 1147 & 1475 & 1329 \\
\cline { 2 - 6 } & & 1852 & 995 & 1061 & \multicolumn{2}{|c}{} \\
\cline { 2 - 6 } & & & & &
\end{tabular}

\begin{tabular}{|l|l|l|l|l|l|}
\cline { 2 - 6 } \multicolumn{1}{c|}{} & 25 & 12 & 12 & 12 & 11 \\
\hline 11 & 28 & 7 & 7 & 3 & 16 \\
\hline 42 & 63 & 23 & 16 & 10 & 27 \\
\hline & 54 & 78 & 36 & 27 & 26 \\
\hline & & 60 & 27 & 34 & \multicolumn{2}{c|}{} \\
\cline { 2 - 6 } & & & &
\end{tabular}

\begin{tabular}{|c|c|c|c|c|c|}
\hline & 139 & 154 & 177 & 92 & 114 \\
\hline 106 & 162 & 58 & 89 & 75 & 87 \\
\hline \multirow[t]{3}{*}{113} & 214 & 106 & 202 & 42 & 178 \\
\hline & 90 & 125 & 67 & 195 & 86 \\
\hline & & 110 & 55 & 104 & \\
\hline
\end{tabular}

Fig. 3. The number of (a) plant species, (b) herbarium records, (c) declared rare and priority plant species and (d) all vertebrate species recorded in half degree grid cells across the study area.

reptile species, 14 frog species and 170 species of bird in the region. Our search of the known distribution of species and their habitat associations suggests there are likely to be an additional 116 vertebrate species (14 mammal, 46 reptile, 6 frog and 50 bird species) present in the region. The grid-cell analysis shows a high degree of spatial variation in the distribution of vertebrate species richness across the region, but there is no general trend in species richness or patterns congruent with the flora (Fig. 3d).

The study area contains (or contained) rare and vulnerable vertebrates and some are locally, regionally or totally extinct. Thirty-one species comprising 15 mammal, 9 bird and 6 species of reptile (Table 2), are listed under the Western Australian Wildlife Conservation Act 1950 (WCA), the Commonwealth of Australia Environment Protection and Biodiversity Conservation Act 1999 (EPBC) or in the IUCN Red List of Threatened Species 2006 (IUCN).

\section{Ecosystem diversity}

Beard (1981) determined vegetation associations based on the dominant structural component of each vegeta- tion community and grouped similar associations into vegetation systems across Western Australia, with each being characterized by a unique set of structural and floristic characteristics. Within the SWAMB there are 141 such vegetation systems. An analysis of this mapping shows that $25(17.7 \%)$ of these are found to some extent within the study area. Six of these systems (named by Beard as 'Bremer Range', 'Cave Hill', 'Forrestania', 'Lake Hope', Parker' and 'Skeleton Rock') occur entirely, or almost entirely within the study area. In addition, there are 5 systems that are more than $50 \%$ contained within the study region. Of the remaining 13 systems, 5 are less than 50\% included and 9 are very marginal to the area $(<5 \%$ included in the study area). These systems are not only unique in their floristic composition, being found nowhere else but have not been wholly or partially cleared or modified.

In Western Australia 18.3 million hectares of native vegetation has been cleared. Nearly all of this is in the SWAFR (Commonwealth of Australia 2001). In light of this, the fact that nearly 6 million hectares of intact vegetation is left in one continuous extent is in itself remarkable. The National Vegetation Inventory (Commonwealth of Australia 2001), identified twenty-three continental 'major 
vegetation groups'. Eleven of these were found in the study region. The continental importance of the region is emphasized by the predominance of three vegetation groups ('eucalypt woodlands', 'Mallee woodlands and shrublands' and 'low closed forests and tall closed shrublands') which have been substantially cleared in other regions of Australia (Table 2; Yates and Hobbs 1999, Yates et al. 1999) (photo 2).

\section{Discussion}

The high number of plant species identified in the study area makes it worthy of global recognition and also confounds the notion that plant species richness decreases away from the tropics (Cowling et al. 1992 in Hopper 1992). One-sixth of Australia's estimated 15000 flower-

Table 1.Vertebrate species that are known to occur $(\mathrm{C})$ or possibly occur $(\mathrm{P})$ in the study area that are listed under the Western Australian Wildlife Conservation Act 1950 (WCA), the Commonwealth of Australia Environment Protection and Biodiversity Conservation Act 1999 (EPBC) or in the IUCN Red List of Threatened Species 2006 (IUCN). WCA: S1 = fauna that is rare or likely to become extinct; $\mathrm{S} 4$ = other specially protected fauna. $\mathrm{EPBC}$ : $\mathrm{EN}$ = endangered; $\mathrm{VU}$ = vulnerable. IUCN: EN = endangered; VU = vulnerable; $\mathrm{DD}=$ data deficient; $\mathrm{LR} / \mathrm{nt}=$ lower risk/near threatened (not strictly threatened category).

\begin{tabular}{llllll}
\hline Taxon & Status & WCA & EPBC & IUCN \\
\hline
\end{tabular}

Reptiles

Aspidites ramsayi Ramsay`s python, woma

C

Echiopsis curta bardick

Egernia stokesii badia

Morelia spilota imbricata carpet python

Paroplocephalus atriceps Lake Cronin snake

Pogona minor minima

Birds

Ardeotis australis Australian bustard

Burhinus grallarius bush stone-curlew

Cacatua leadbeateri Major Mitchell`s cockatoo

Calyptorhynchus latirostris Carnaby`s cockatoo

Falco hypoleucos grey falcon

Falco peregrinus peregrine falcon

Leipoa ocellata malleefowl

Polytelis alexandrae princess parrot

Psophodes nigrogularis western whipbird

Mammals

Antechinomys laniger kultarr

Bettongia penicillata brush-tailed bettong, woylie

Canis lupus dingo

Dasycercus cristicauda mulgara

Dasyurus geoffroii western quoll, chuditch

Isoodon obesulus obesulus southern brown bandicoot, quenda

Macropus eugenii tammar wallaby

Macropus irma western brush wallaby

Myrmecobius fasciatus numbat, walpurti, banded anteater

Nyctophilus timoriensis greater long-eared bat

Parantechinus apicalis southern dibbler

Petrogale lateralis lateralis black-footed rock-wallaby

Phascogale calura red-tailed phascogale

Pseudomys shortridgei heath rat

Tadarida australis white-striped freetail-bat

$\begin{array}{llll}\text { C } & & & \text { VU } \\ \text { P } & \text { S1 } & \text { EN } & \text { EN } \\ \text { C } & \text { S4 } & & \text { LR/nt } \\ \text { C } & \text { S1 } & & \text { VU } \\ \text { C } & \text { S1 } & & \end{array}$

NT

NT

C S4

C S1

C

C

C

$\mathrm{P}$

C

$\mathrm{S} 1$

EN

EN

NT

S4

S1

$\mathrm{VU}$

VU

VU NT

S1

EN

NT

DD

$\mathrm{LR} / \mathrm{nt}$

$\mathrm{VU}$

C

$\mathrm{VU}$

$\begin{array}{llll}C & S 1 & \text { VU } & \text { VU }\end{array}$

$\mathrm{P}$

EN LR/nt

P

$\mathrm{LR} / \mathrm{nt}$

C

$\mathrm{LR} / \mathrm{nt}$

C

C

$\mathrm{P}$

VU

VU

$\mathrm{VU}$

EN EN

VU VU

$\mathrm{P} \quad \mathrm{S} 1$

EN EN

$\begin{array}{llll}\mathrm{C} & \mathrm{S} 1 & \mathrm{EN} & \mathrm{EN} \\ \mathrm{P} & \mathrm{S} 1 & \mathrm{VU} & \mathrm{LR} / \mathrm{nt}\end{array}$

C
$\mathrm{LR} / \mathrm{nt}$ 
ing plant species (Commonwealth of Australia 2001) were recorded. This is less than the number of species found by Hopper and Gioia (2004) in the SWAFR (over 7300 species, see Fig. 1 for SWAFR) but their research covered an area four times the size of our study area, and which has been surveyed more thoroughly and covers a greater rainfall gradient (Verboom and Pate 2006).

One of the reasons for the high richness of flora is because the southwest corner of the study area falls within a large rainfall gradient known as the Transitional Rainfall Zone (TRZ, Hopper 1979). Rainfall has had a major effect on the speciation and current distribution of the southwest Australia flora (Beard 1984, Hopper 1979, Hopper and Gioia 2004). In the past, the southwest experienced intense, long-term climatic pulses between wet and dry conditions, leaving a very rich and locally-adapted flora, especially in the TRZ (Hopper and Gioia 2004). This may account for the study area's high species richness and also for the clear trend of species richness declining as it moves southwest to northeast, which follows a decline in the rainfall gradient (Fig. 1). The southwest of the region is not well represented in conservation tenure (Fig. 2) and is adjacent to The Fitzgerald River National Park, one of the largest and botanically the richest national park in Western Australia (Dept of Conservation and Land Management 1991). The southwest of our study area shows similar levels of floristic diversity with associations that change rapidly over relatively small spatial scales (Newbey and Hnatiuk 1984, 1988, Burgman 1988, Newbey et al. 1995) and merits conservation tenure on this statistic alone. In addition, it contains relictual populations of rare and threatened flora once more widely distributed through what are now primarily cleared agricultural lands.

Vertebrate species richness was not high compared to other Mediterranean ecoregions in Australia and around the world (Wilson et al. 2007). However, the number of species not recorded, but believed to occur in the study area based on habitat preference and known geographic range, suggests that it is higher than indicated. The area is an important reptile habitat with communities that are spatially and temporally variable reflecting the heterogeneous vegetation communities and periodic rainfall events that occur in the region (Cowan and How 2004, Thompson and Thompson 2005).

The region may be a refuge for many species that are currently declining in other areas of Australia. The region contains extensive cover of the major vegetation groups that have had large proportions of their original range cleared in other parts of Australia (Table 1). These vegetation groups provide habitat for a range of species that have declining populations in other regions of Australia where landscape alteration has been significant (Recher 1999, Ford et al. 2001, Watson et al. 2008). For example, of Australia's remaining $693449 \mathrm{~km}^{2}$ of eucalypt woodland we calculate that $81008 \mathrm{~km}^{2}(12 \%)$ occurs in our study area.

\section{Conservation management of the region}

Our synthesis shows there is a need for more ecological research to be conducted in the region. This part of SWAMB has had considerably less scientific attention than other areas, and using Whittaker et al.'s (2005) terminology, there are significant 'Wallacean' (i.e. knowledge on species geographic and temporal range in the region) and 'Linnaean' (i.e. knowledge on how many species actually live in the region) shortfalls for all the major species groups. Thus more research is required to understand the key values of the system and to optimize management strategies (Hop-

Table 2. The continental area $\left(\mathrm{km}^{2}\right)$ of both pre-European (1788) and current (2001), vegetation cover of each of the 11 major vegetation groups found in study area according to the National Vegetation Inventory (Commonwealth of Australia 2001). The area $\left(\mathrm{km}^{2}\right)$ cover of each group within the study area is also shown.

\begin{tabular}{lllll}
\hline Major vegetation group & Pre-1788 & Cleared & $\begin{array}{l}\text { Cleared } \\
(\%)\end{array}$ & $\begin{array}{l}\text { Study } \\
\text { area }\end{array}$ \\
\hline Eucalypt low open forests & 15066 & 2144 & 14.2 & 44 \\
Eucalypt woodlands & 1012047 & 318598 & 31.4 & 81008 \\
Callitris forests and woodlands & 30963 & 3239 & 10.5 & 4 \\
Eucalypt open woodlands & 513943 & 129633 & 25.2 & 36 \\
Acacia open woodlands & 117993 & 3238 & 2.7 & 204 \\
Mallee woodlands and shrublands & 383399 & 132979 & 34.7 & 13483 \\
Low closed forests and tall closed shrublands & 15864 & 7115 & 44.9 & 7669 \\
Acacia shrublands & 670737 & 16458 & 2.5 & 755 \\
Other shrublands & 115824 & 16877 & 14.6 & 4832 \\
Hummock grasslands & 1756962 & 858 & 0.1 & 48 \\
Chenopod shrublands, samphire shrublands and forblands & 563389 & 10995 & 2.0 & 1086 \\
\hline
\end{tabular}


per and Gioia 2004, Whittaker et al. 2005). More research on taxa not included in our synthesis should seek to reveal the extent of endemic species within different groups and the degree of variety of distributional patterns. For example, the area may be valuable for invertebrate conservation, given the loss of invertebrates observed in the adjacent wheat belt (Abensperg-Traun et al. 2000).

In the absence of a complete knowledge of the taxa present and their distributions, one approach is to protect and manage for critical elements of ecosystem function. This requires more research that examines the landscapewide ecological processes that sustain its biodiversity (Soulé et al. 2004, Woinarski et al. 2007). These processes, which include 'eco-hydrology' (defined as 'the relationships between water (both surface and ground water), vegetation, wildlife, and landforms at local and regional scales', Soulé et al. 2004, Mackey et al. 2007), trophically important species (e.g. dingos, pollinators, Soulé et al. 2003), and ecologically appropriate fire regimes (Woinarksi 1999), need to be understood if a suitable, long-term conservation plan is to be developed for the area.

Less than $15 \%$ of the study area is formally protected or allocated resources for conservation, with the majority of the region being land which has no statutory allocated tenure and is therefore technically the property of the crown. (Fig. 1 in Watson et al. 2008). The patterns of plant species richness identified in this study alone suggest that it is a highly significant Mediterranean ecosystem. Despite an incomplete knowledge, there are opportunities and imperatives for long-term conservation action. Therefore, we call for a landscape-wide conservation plan to be developed for the region that involves targeted ecological research and consultation with traditional owners, State and Federal Governments, and those resource-based industry groups which are increasingly utilizing the region.

\section{Conclusions}

We have synthesized all the readily available information on the biological values of an important but little known part of the Mediterranean biome of southwest Australia. Our findings highlight the gaps in our current knowledge of the area. The challenge now and in the coming decades is to maintain the natural values of this region, protect the ecological processes that sustain these values, and repair any environmental damage that has already occurred.

\footnotetext{
Acknowledgements - We acknowledge the Wind over Water Foundation for helping to fund this research. We thank Sandy Berry, Keith Bradby, Angas Hopkins, Pierre Horwitz, Anya Lam, Nina Rabe, Harry Recher, Charles Roche, Sean Stankowski and Jill StJohn for research assistance or for providing comment on earlier drafts of the manuscript. We also acknowledge the contribution of members of the WildCountry Science Council. Scott Thompson, Graham Thompson and Thomas Rasmussen provided expertise with the reptiles. Geographic data for this study
}

were licensed to the primary author by the Western Australian Dept of Agriculture and Food (Beard's pre-European vegetation mapping) and the Western Australian Dept of Environment and Conservation (land tenure) and we thank the helpful staff at these organizations. National Vegetation Information System (NVIS) data are available from the Australian Government Dept of the Environment, Water, Heritage and the Arts at <http:// www.environment.gov.au/erin/nvis/index.html>.

\section{References}

Abensperg-Traun, M. et al. 2000. Different woodland types, different grazing effects. Plants and soil and litter arthropods in remnant woodlands in the Western Australian wheatbelt. In: Hobbs, R. J. et al. (eds), Temperate eucalypt woodlands in Australia: biology, conservation, management and restoration. Surrey Beatty and Sons, pp: 225-234.

Anand, R. R. and Paine, M. 2002. Regolith geology of the Yilgarn Craton, Western Australia: implications for exploration. - Aust. J. Earth Sci. 49: 3-162.

Arnold, G. W. and Weeldenburg, J. R. 1998. The effects of isolation, habitat fragmentation and degradation by livestock grazing on the use by birds of Gimlet Eucalyptus salubris woodland in the wheatbelt of Western Australia. - Pac. Conserv. Biol. 4: 155-163.

Beard, J. S. 1980. A new phytogeographic map of Western Australia. - West. Aust. Herb. Res. Notes 3: 37-58.

Beard, J. S. 1981. The vegetation of Western Australia at the 1:3 000000 scale (with map). - Forests Dept, Western Aust. State Gov.

Beard, J. S. 1984. Biogeography of the Kwongan. - In Pate, J. S. and Beard, J. S. (eds), Kwongan: plant life of the sand plain. - Univ. of Western Australia Press, pp: 1-26.

Bureau of Meteorology 2008. Climate information for Australia, <http://www.bom.gov.au/climate/forms/map_forms/imagemap.shtml>.

Burgman, M. A. 1988. Spatial analysis of vegetation patterns in southern Western Australia: implications for reserve design. - Aust. J. Ecol. 13: 415-429.

Cody, M. L. 1986. Diversity, rarity and conservation in Mediterranean-climate regions. - In: Soulé, M. E. (ed.), Conservation biology. The science of scarcity and diversity. Sinauer, pp: 122-152.

Commonwealth of Australia 2001. Australia's natural resources 1997-2002 and beyond. Australian Native Vegetation Assessment. - Natl Land Water Res. Audit.

Cowan, M. A. and How, R. A. 2004. Comparisons of ground vertebrate assemblages in arid Western Australia in different seasons and decades. - Rec. West. Aust. Mus. 22: 91-100.

Cowling, R. M. et al. 1996. Plant diversity in Mediterraneanclimate regions. - Trends Ecol. Evol. 11: 362-366.

Department of Conservation and Land Management 1991. Fitzgerald River National Park management plan 1991-2001. - Western Aust. Dept Conserv. Land Manage., Perth.

Department of Environment and Conservation 2008. Florabase. Western Australian flora conservation taxa. - Western Aust. Herb. <http://florabase.calm.wa.gov.au/conservationtaxa>.

Ford, H. A. et al. 2001. Why have birds in the woodlands of southern Australia declined? - Biol. Conserv. 97: 71-88.

Greuter, W. 1994. Extinction in Mediterranean areas. - Philos. Trans. R. Soc. Lond. B 344: 41-46. 
Hobbs, R. J. and Atkins, L. 1991. Interactions between annuals and woody perennials in a Western Australian nature reserve. - J. Veg. Sci. 2: 643-654.

Hobbs, R. J. and O'Connor, M. H. 1999. Designing mimics from incomplete data sets: salmon gum woodland and heathland ecosystems in southwest Australia. - J. Agroforest. Syst. 45: 365-394.

Hopper, S. D. 1979. Biogeographic aspects of speciation in the southwest Australian flora. - Annu. Rev. Ecol. Syst. 10: 399-422.

Hopper, S. D. 1992. Patterns of plant diversity at the population and species level in southwest Australian Mediterranean ecosystems. - In: Hobbs, R. J. (ed.), Biodiversity of Mediterranean ecosystems in Australia. Surrey Beatty and Sons, pp: $27-46$.

Hopper, S. D. 2003. Southwestern Australia, Cinderella of the world's temperate floristic regions, 1. - Curtis's Bot. Mag. 20: $101-126$.

Hopper, S. D. 2004. Southwestern Australia, Cinderella of the world's temperate floristic regions, 2. - Curtis's Bot. Mag. 21: $132-180$.

Hopper, S. D. and Muir, B. G. 1984. Conservation of the Kwongan. - In: Pate, J. S. and Beard, J. S. (eds), Kwongan: plant life of the sandplain. Univ. of Western Australian Press, Perth. pp. 253-266.

Hopper, S. D. et al. 1996. Gondwanan heritage: past, present and future of the Western Australian biota. - Surrey Beatty and Sons.

Hopper, S. D. and Gioia, P. 2004. The southwest Australian floristic region: evolution and conservation of a global biodiversity hotspot. - Annu. Rev. Ecol. Syst. 35: 623-650.

How, R. A. et al. 1998. Biological survey of the eastern goldfields of Western Australia. Part 4. Lake Johnston-Hyden study area. - Rec. West. Aust. Mus. Suppl. 30: 1-233.

IUCN 2006. IUCN red list of threatened species. - IUCN Gland, Switzerland.

Keighery, G. J. et al. 1995. Biological survey of the eastern goldfields of Western Australia. Part 11. Boorabbin-Southern Cross study area. - Rec. West. Aust. Mus. Suppl. 49: $1-312$.

Mackey, B. G. et al. 2007. Towards a scientific framework for the WildCountry project. - In: Wu, J. and Hobbs, R. J. (eds), Key topics and perspectives in landscape ecology. Cambridge Univ. Press, pp. 92-208.

Myers, N. et al. 2000. Biodiversity hotspots for conservation priorities. - Nature 403: 853-858.

Newbey, K. R. et al. 1984. Biological survey of the eastern goldfields of Western Australia. Part 2. Widgiemooltha-Zanthus study area. - Rec. West. Aust. Mus. Suppl. 18: 1-158.

Newbey, K. R. and Hnatiuk, R. J. 1984. Vegetation and flora. - In: Newbey, K. R. et al. (eds), Biological survey of the eastern goldfields of Western Australia. Part 2. WidgiemoolthaZanthus study area. - Rec. West. Aust. Mus. Suppl. 18: 41-56.
Newbey, K. R. and Hnatiuk, R. J. 1988. Vegetation and flora. In: How, R. A. et al. (eds), Biological survey of the eastern goldfields of Western Australia. Part 4. Lake Johnston-Hyden study area. - Rec. West. Aust. Mus. Suppl. 30: 17-43.

Newbey, K. R. et al. 1995. Vegetation and flora. - In: Keighery, G. J. et al. (eds), Biological survey of the eastern goldfields of Western Australia. Part 11. Boorabbin-Southern Cross study area. - Rec. West. Aust. Mus. Suppl. 49: 17-30.

Recher, H. F. 1999. The state of Australia’s avifauna: a personal opinion and prediction for the new millennium. - Aust. Zool. 31: 11-27.

Saunders, D. A. et al. 1992. Biological consequences of ecosystem fragmentation: a review. - Conserv. Biol. 5: 18-28.

Saunders, D. A. and Ingram, J. A. 1995. Birds of southwestern Australia: an atlas of changes in the abundance and distribution of the wheatbelt avifauna. - Surrey Beatty and Sons.

Soulé, M. E. et al. 2003. Ecological effectiveness: conservation goals for interactive species. - Conserv. Biol. 17: $1238-1250$.

Soulé, M. E. et al. 2004. The role of connectivity in Australian conservation. - Pac. Conserv. Biol. 10: 266-279.

Thackway, R. and Lesslie, R. 2006. Reporting vegetation condition using the Vegetation Assets, States and Transitions (VAST) framework. - Ecol. Manage. Restor. 7: S53-S62.

Thompson, S. A. and Thompson, G. G. 2005. Temporal variations in reptile assemblages in the goldfields of Western Australia. - J. R. Soc. West. Aust. 88: 25-36.

Verboom, W. H. and Pate, J. S. 2006. Evidence of active biotic influences in pedogenetic processes. Case studies from semiarid ecosystems of southwest Western Australia. - Plant Soil 289: 103-121.

Watson, A. W. T. et al. 2008. The extraordinary nature of the Great Western Woodlands. - Wilderness Soc., Perth.

Whittaker, R. J. et al. 2005. Conservation biogeography: assessment and prospect. - Divers. Distrib. 11: 3-23.

Wilson, K. A. et al. 2007. Conserving biodiversity efficiently: what to do, where, and when. - PLoS Biol. 5: 1850-1861.

Woinarksi, J. C. Z. 1999. Fire and Australian birds: a review. In: Gill, A. M. et al. (eds), Australia's biodiversity: responses to fire: plants, birds and invertebrates. - Environment Australia, Canberra, pp. 55-111.

Woinarksi J. C. Z. et al. 2007. The nature of northern Australia: natural values, ecological processes and future prospects. Aust. Natl Univ. Press.

Yates, C. J. et al. 1999. The distribution and status of eucalypt woodlands in Western Australia. - In: Hobbs, R. J. et al. (eds), Temperate eucalypt woodlands in Australia: biology, conservation, management and restoration. Surrey Beatty and Sons, pp. 86-106.

Yates, C. J. and Hobbs, R. J. 1999. Temperate eucalypt woodlands in Australia - an overview. - In: Hobbs, R. J. et al. (eds), Temperate eucalypt woodlands in Australia: biology, conservation, management and restoration. Surrey Beatty and Sons, pp. 1-5. 